Supporting information for

\title{
Construction of multi-enzyme co-immobilized hybrid nanoflowers for efficient conversion of cellulose into glucose in cascade reaction
}

\author{
Juan Han, ${ }^{\dagger \dagger, \$}$ Hui Feng, ${ }^{\ddagger}$ Jiacong Wu, ${ }^{\dagger}$ Yuanyuan Li, ${ }^{\S}$ Yang Zhou, $\|$ Lei Wang, ${ }^{\dagger} \quad$ Peng Luo, ${ }^{\ddagger}$ \\ Yun Wang,,$\dagger$ \\ ${ }^{\dagger}$ School of Chemistry and Chemical Engineering, Jiangsu University, Zhenjiang 212013, PR China \\ \$School of Food and Biological Engineering, Jiangsu University, Zhenjiang 212013, PR China \\ $\S$ Jingjiang College, Jiangsu University, Zhenjiang 212013, PR China \\ " Institute of Life Sciences, Jiangsu University, Zhenjiang 212013, PR China
}

\begin{abstract}
AUTHOR INFORMATION
* Corresponding Author

Dr. Juan Han, ORCID: 0000-0001-9472-0647, E-mail: hanjuan@ujs.edu.cn

Prof. Dr. Yun Wang, ORCID: 0000-0003-0024-0824, E-mail: yunwang@ujs.edu.cn
\end{abstract}




\section{EXPERIMENTAL SECTION}

Construction and Expression of Fusion Proteins: The recombinant plasmid of pET-Glu-linker-ELP-6His (pET-GLEH) in this experiment was constructed in our previous study ${ }^{1}$. And the recombinant plasmids of pET-EG-linker-ELP-6His (pETEGLEH) and pET-CBH-linker-ELP-6His (pET-CBHLEH) were constructed by Synbio Tech (Suzhou, China). Then, the different recombinant plasmids were transformed into $E$. coli BL21 cells for the expression of fusion gene. Firstly, the starter culture was prepared by transferring BL21 cells to $7 \mathrm{~mL}$ Luria-Bertani (LB) medium containing $7 \mu \mathrm{L}$ kanamycin for growing overnight. Subsequently, the obtained starter culture was inoculated in $200 \mathrm{~mL}$ LB medium with $200 \mu \mathrm{L}$ kanamycin at a ratio of 1:1000 to express EGLEH and CBHLEH. The LB medium containing BL21 cells was cultured under the conditions of $190 \mathrm{rpm}$ at 37 ${ }^{\circ} \mathrm{C}$ until the $\mathrm{OD}_{600 \mathrm{~nm}}$ value reached $0.4-0.6$, followed by incubation in ice bath to cool the medium. A certain amount of IPTG with the final concentration of $0.25 \mathrm{mM}$ was added into the LB medium to induce the expression of EGLEH and CBHLEH at $15{ }^{\circ} \mathrm{C}$ with shaking at $190 \mathrm{rpm}$ for $12 \mathrm{~h}$. After induction, BL21 cells were collected by centrifugation and washed by PBS (pH 7.5, $10 \mathrm{mM})$. Finally, the obtained BL21 cell pellets were stored at $-80{ }^{\circ} \mathrm{C}$ for the following study.

Purification of Fusion Proteins: The frozen BL21 cell pellets were thawed and suspended with $10 \mathrm{~mL}$ PBS (pH 7.5, $10 \mathrm{mM}$ ) containing 100 $\mu \mathrm{L}$ PMSF (100 mM). BL21 cell pellets were broken by ultrasonication in ice bath. Subsequently, the cell debris was removed by centrifugation $\left(13000 \mathrm{~g}, 30 \mathrm{~min}, 4^{\circ} \mathrm{C}\right)$ and the supernatant was kept as crude 
extract. Since GLEH had already been studied by our group, the next experiment focused on EGLEH and CBHLEH. The purification of EGLEH and CBHLEH was carried out and the specific experiments were as follows: a certain concentration of $\left(\mathrm{NH}_{4}\right)_{2} \mathrm{SO}_{4}$ and a crude enzyme solution were mixed at $25{ }^{\circ} \mathrm{C}$ for some time, after centrifugation, the precipitation was collected. Then, the EGLEH and CBHLEH in precipitation was suspended using cold PBS $(\mathrm{pH} 7.5,10 \mathrm{mM})$ and the solution was incubated at $4{ }^{\circ} \mathrm{C}$ for $1 \mathrm{~h}$ to redissolve EGLEH and CBHLEH. Finally, the EGLEH and CBHLEH were collected in the supernatant after refrigerated centrifugation. In addition, the activity recovery and purification fold of EGLEH and CBHLEH were determined as below:

activity recovery $(\%)=\frac{\text { purified enzyme activity }}{\text { crude enzyme activity }} \times 100 \%$

purification fold $=\frac{\text { specific activity of purified enzyme }}{\text { specific activity of crude enzyme }}$

Preparation of EC@G-NFs: $30 \mu \mathrm{LuSO}_{4}(0.14 \mathrm{M})$ solution was added to $1 \mathrm{~mL}$ PBS (10 mM, pH 7.5) containing $0.11 \mathrm{mg} \mathrm{mL}^{-1} \mathrm{GLEH}$, followed by incubation at $4{ }^{\circ} \mathrm{C}$ for 12 h. After the incubation, the GLEH-NFs was collected through centrifugation and washed with water for three times to remove the excess GLEH. Subsequently, GLEH-NFs was added to $1 \mathrm{~mL}$ of deionized water containing $0.28 \mathrm{mg} \mathrm{mL}^{-1}$ EGLEH and $0.11 \mathrm{mg} \mathrm{mL}^{-1}$ CBHLEH, followed by incubation at $4{ }^{\circ} \mathrm{C}$ for $12 \mathrm{~h}$. Finally, the EC@G-NFs was obtained.

Preparation of G@EC-NFs: typically, $30 \mu \mathrm{L} \mathrm{CuSO}_{4}(0.14 \mathrm{M})$ solution was added to 1 $\mathrm{mL}$ PBS (10 mM, pH 7.5) containing $0.28 \mathrm{mg} \mathrm{mL}^{-1}$ EGLEH and $0.11 \mathrm{mg} \mathrm{mL}^{-1} \mathrm{CBHLEH,}$ followed by incubation at $4{ }^{\circ} \mathrm{C}$ for $12 \mathrm{~h}$. After the incubation, the EC-NFs was collected through centrifugation and washed with water for three times. Subsequently, EC-NFs was 
added to $1 \mathrm{~mL}$ of deionized water containing $0.11 \mathrm{mg} \mathrm{mL}^{-1} \mathrm{GLEH}$, followed by incubation at $4{ }^{\circ} \mathrm{C}$ for $12 \mathrm{~h}$ to obtain the $\mathrm{G} @ \mathrm{EC}-\mathrm{NFs}$.

\section{RESULTS AND DISCUSSION}

Construction and Expression of EGLEH、CBHLEH and GLEH. The recombinant EGLEH, CBHLEH and GLEH were constructed by inserting linker between binary label (ELP-His) and target enzymes. In the induced expression of EGLEH, CBHLEH and GLEH, the concentration of IPTG, temperatures and time can influence the expression results. According to our previous study on the expression of GLEH, temperatures and time were determined to be $25^{\circ} \mathrm{C}$ for $6 \mathrm{~h}$, and the concentration of IPTG was $0.35 \mathrm{mM}^{1}$. As shown in Table S1, the specific enzyme activity of EGLEH reached the maximum value of 8.42 $\mathrm{U} \mathrm{g}^{-1}$ at the IPTG concentration of $0.25 \mathrm{mM}$ and the specific enzyme activity of CBHLEH reached the maximum value of $4.14 \mathrm{U} \mathrm{g}^{-1}$ at the IPTG concentration of $0.35 \mathrm{mM}$. The results can also be verified by SDS gel electrophoresis (Figure S1). Thus, $0.25 \mathrm{mM} \mathrm{IPTG}$ and $0.35 \mathrm{mM}$ IPTG were selected for the expression of EGLEH and CBHLEH, respectively. In addition, Table S2 and Figure S2 showed the specific enzyme activity of EGLEH and CBHLEH at different temperatures and time. It can be concluded that the temperatures and time of EGLEH and CBHLEH were determined to be $15^{\circ} \mathrm{C}$ for $12 \mathrm{~h}$.

Purification of EGLEH, CBHLEH and GLEH. The EGLEH, CBHLEH and GLEH were separated and purified by ITC method, which can be divided into two important steps: "hot precipitation" and "cold fusion". The process of ITC was shown in Figure S4. 
Additionally, it is well known that the phase transition temperature of ELP was so high that the activity of enzyme will be lost, but the phase transition temperature can be reduced by adding electrolyte. According to our previous work on $\mathrm{GLEH}^{2},\left(\mathrm{NH}_{4}\right)_{2} \mathrm{SO}_{4}$ was chosen to reduce the phase transition temperature of ELP. Thus, in order to investigate the optimal salt concentration of electrolytes on the purification of recombinant enzymes, a series of concentrations of $\left(\mathrm{NH}_{4}\right)_{2} \mathrm{SO}_{4}(0.2 \mathrm{M}-0.8 \mathrm{M})$ were selected to purify EGLEH, CBHLEH and GLEH. The optimal enzyme activity recovery rate and purification fold of GLEH were achieved in the concentration of $\left(\mathrm{NH}_{4}\right)_{2} \mathrm{SO}_{4}$ was $0.4 \mathrm{M}$ and the time of "hot precipitation" was $10 \mathrm{~min}$.

As displayed in Figure $\mathrm{S} 5$, when the concentration of $\left(\mathrm{NH}_{4}\right)_{2} \mathrm{SO}_{4}$ was $0.8 \mathrm{M}$, the enzyme activity recovery of EGLEH reached the maximum value of $81.7 \%$ and the purification multiple reached 9.8. Similarly, the enzyme activity recovery of CBHLEH reached the maximum value of $36.0 \%$ at $1.0 \mathrm{M}\left(\mathrm{NH}_{4}\right)_{2} \mathrm{SO}_{4}$, and the purification multiple reached 9.8 (Figure S5(b)). In addition, the gel electrophoresis results of EGLEH and CBHLEH purified at different concentrations of $\left(\mathrm{NH}_{4}\right)_{2} \mathrm{SO}_{4}$ can further confirmed the results, the detailed results were showed in Figure S3. Thus, $0.8 \mathrm{M}\left(\mathrm{NH}_{4}\right)_{2} \mathrm{SO}_{4}$ and $1.0 \mathrm{M}\left(\mathrm{NH}_{4}\right)_{2} \mathrm{SO}_{4}$ were selected as the optimum precipitant for the following purification of EGLEH and CBHLEH, respectively. Moreover, Figure S5(c)-(d) showed the effect of the "hot precipitation" time in ITC purification of EGLEH and CBHLEH, when the "hot precipitation" time was $20 \mathrm{~min}$, the purification multiple and enzyme activity recovery rate of these two enzymes reached a stable value. Thus, 20 min was taken as the best "hot 
precipitation" time.

Furthermore, the purity of EGLEH and CBHLEH obtained by ITC purification process with different numbers of ITC process was analyzed and the results were shown in Table S3. The results showed that enzyme activity recovery and purification fold of EGLEH (CBHLEH) after the first round of ITC were higher than those after the second round of ITC, so the high purity and recovery rate of EGLEH and CBHLEH could be obtained by just one round of ITC. In addition, the optimal reaction temperature of EGLEH and CBHLEH was determined as $40{ }^{\circ} \mathrm{C}$ and $50{ }^{\circ} \mathrm{C}$, and the optimal $\mathrm{pH}$ value of EGLEH and CBHLEH was 4 and 5 (Figure S6).
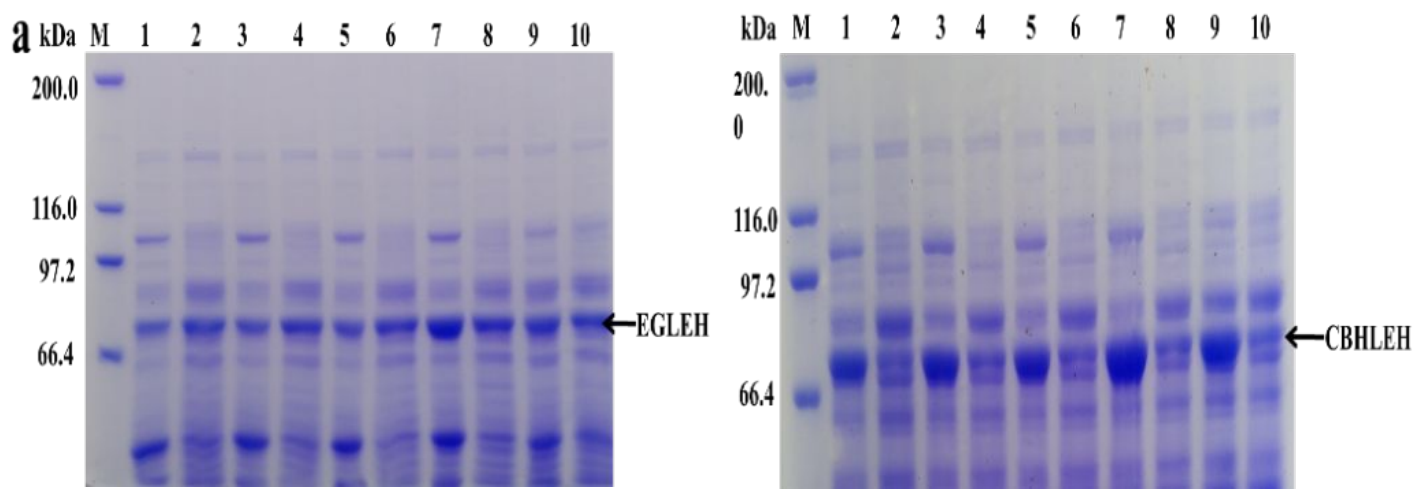

Figure S1. (a) The SDS-PAGE results of (a) EGLEH and (b) CBHLEH induced at different IPTG concentration. From left to right: Lane M: Protein molecular weight marker; Lane 1: lysate precipitation after $0.15 \mathrm{mM}$ IPTG induced; Lane 2: lysate supernatant after $0.15 \mathrm{mM}$ IPTG induced; Lane 3: lysate precipitation after $0.25 \mathrm{mM}$ IPTG induced; Lane 4: lysate supernatant after $0.25 \mathrm{mM}$ IPTG induced; Lane 5: lysate precipitation after $0.35 \mathrm{mM}$ IPTG induced; Lane 6: lysate supernatant after $0.35 \mathrm{mM}$ IPTG induced; Lane 7: lysate precipitation after $0.45 \mathrm{mM}$ IPTG induced; Lane 8: lysate supernatant 
after $0.45 \mathrm{mM}$ IPTG induced; Lane 9: lysate precipitation after $0.55 \mathrm{mM}$ IPTG induced; Lane 10: lysate supernatant after $0.55 \mathrm{mM}$ IPTG induced.

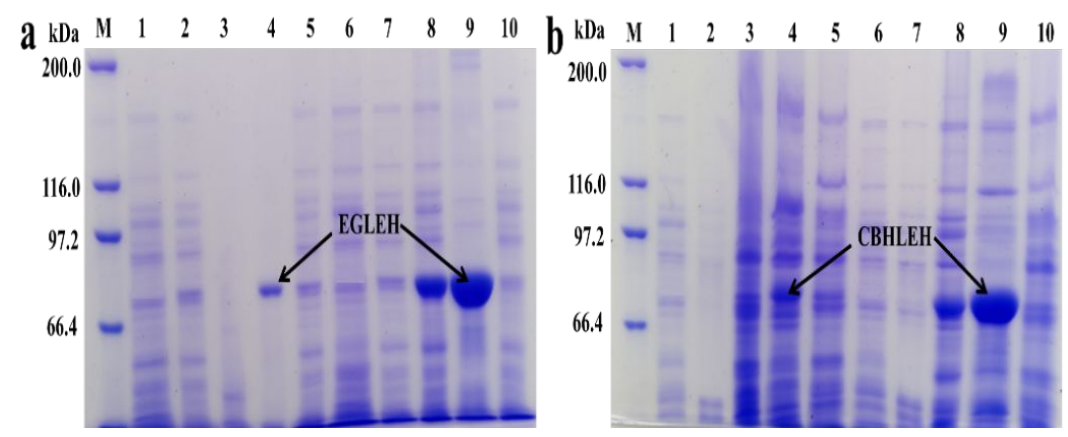

Figure S2. The SDS-PAGE results of (a) EGLEH induced at $15{ }^{\circ} \mathrm{C}$ for $12 \mathrm{~h}$ and at $37^{\circ} \mathrm{C}$ for $12 \mathrm{~h}$ and (b) $\mathrm{CBHLEH}$ induced at $15^{\circ} \mathrm{C}$ for $12 \mathrm{~h}$ and at $37^{\circ} \mathrm{C}$ for $12 \mathrm{~h}$. Lane M: Protein molecular weight marker; Lane 1: Lytic supernatant induced by BL21 of pET28a $(+)$ at $15^{\circ} \mathrm{C}$ for $12 \mathrm{~h}$; Lane 2: Uninduced whole bacteria BL21 containing EGLEH gene; Lane 3: The whole bacteria of BL21 containing EGLEH gene were induced at $15^{\circ} \mathrm{C}$ for $12 \mathrm{~h}$; Lane 4: Precipitation of BL21 containing EGLEH gene at $15^{\circ} \mathrm{C}$ for $12 \mathrm{~h}$; Lane 5: Supernatant of BL21 containing EGLEH gene at $15{ }^{\circ} \mathrm{C}$ for $12 \mathrm{~h}$; Lane 6: Lytic supernatant induced by BL21 of empty carrier pET28a(+) at $37{ }^{\circ} \mathrm{C}$ for $12 \mathrm{~h}$; Lane 7: Uninduced whole bacteria BL21 containing EGLEH gene; Lane 8: The whole bacteria of EGLEH containing BL21 induced at $37^{\circ} \mathrm{C}$ for $12 \mathrm{~h}$; Lane 9: Precipitation of BL21 containing EGLEH gene induced at $37^{\circ} \mathrm{C}$ for $12 \mathrm{~h}$; Lane 10: Supernatant of BL21 containing EGLEH gene at $37{ }^{\circ} \mathrm{C}$ for $12 \mathrm{~h}$. In Figure B, Lane M: Protein molecular weight marker; Lane 1: Lytic supernatant induced by BL21 of empty carrier pET28a(+) at 15 ${ }^{\circ} \mathrm{C}$ for 12h; Lane 2: Uninduced whole bacteria BL21 containing CBHLEH gene; Lane 3: The whole bacteria of BL21 containing CBHLEH gene were induced at $15^{\circ} \mathrm{C}$ for $12 \mathrm{~h}$; Lane 4: Precipitation of BL21 containing CBHLEH gene at $15^{\circ} \mathrm{C}$ for $12 \mathrm{~h}$; Lane 5: Supernatant of BL21 containing CBHLEH 
gene at $15{ }^{\circ} \mathrm{C}$ for $12 \mathrm{~h}$; Lane 6: Lytic supernatant induced by BL21 of empty carrier pET28a(+) at $37{ }^{\circ} \mathrm{C}$ for $12 \mathrm{~h}$; Lane 7: Uninduced whole bacteria BL21 containing CBHLEH gene; Lane 8: The whole bacteria of CBHLEH containing BL21 induced at $37{ }^{\circ} \mathrm{C}$ for $12 \mathrm{~h}$; Lane 9: Precipitation of BL21 containing CBHLEH gene induced at $37{ }^{\circ} \mathrm{C}$ for $12 \mathrm{~h}$; Lane 10: Supernatant of BL21 containing CBHLEH gene at $37^{\circ} \mathrm{C}$ for $12 \mathrm{~h}$.
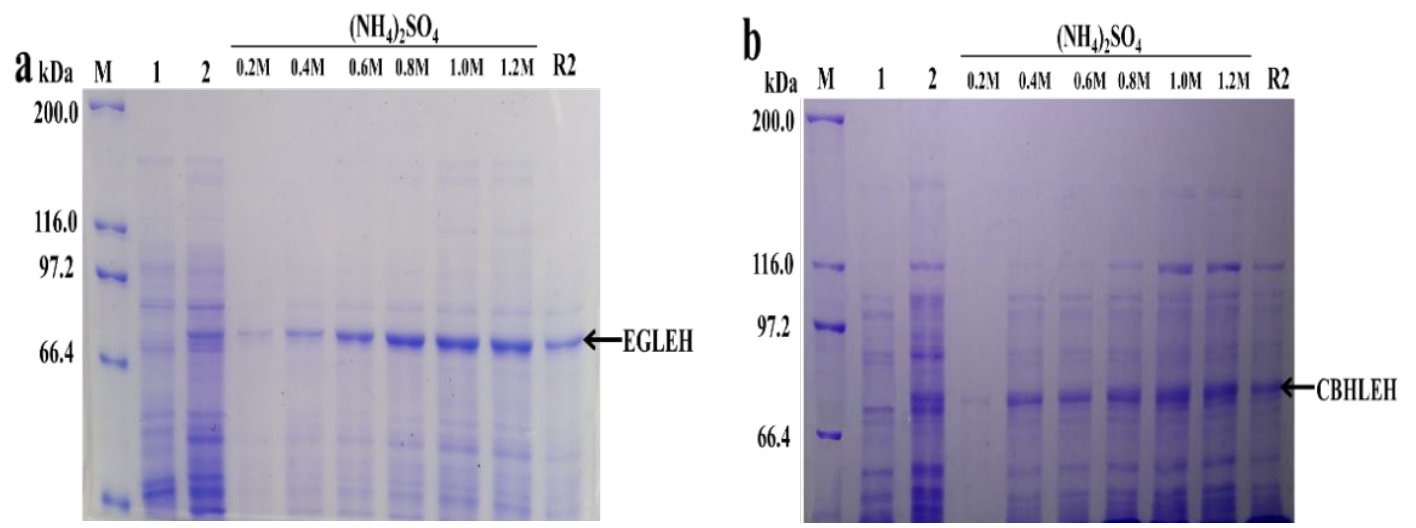

Figure S3. The SDS-PAGE results of (a) EGLEH and (b) CBHLEH after purification by ITC. Lane M:

Protein molecular weight marker; Lane 1: Empty carrier induces expression of broken supernatant; Lane 2: Uninduced whole bacteria BL21 containing EGLEH gene; Lane 0.2-1.2M: products of EGLEH with different concentrations $\left(\mathrm{NH}_{4}\right)_{2} \mathrm{SO}_{4}$; Lane 2: the purified product of EGLEH after two ITC rounds. In Figure (b), Line M: Protein molecular weight marker; Lane 1: Empty carrier induces expression of broken supernatant; lane 2: Uninduced whole bacteria BL21 containing CBHLEH gene; Lane 0.2-1.2M: products of CBHLEH with different concentrations $\left(\mathrm{NH}_{4}\right)_{2} \mathrm{SO}_{4}$; Lane 2: the purified products of CBHLEH after two ITC rounds. 


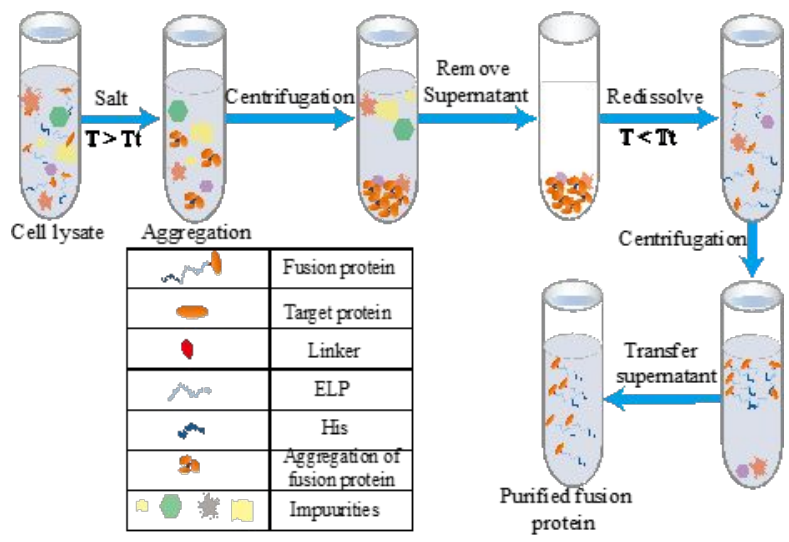

Figure S4. Schematic illustration of the purification of fusion protein with ELP-His tags by ITC.
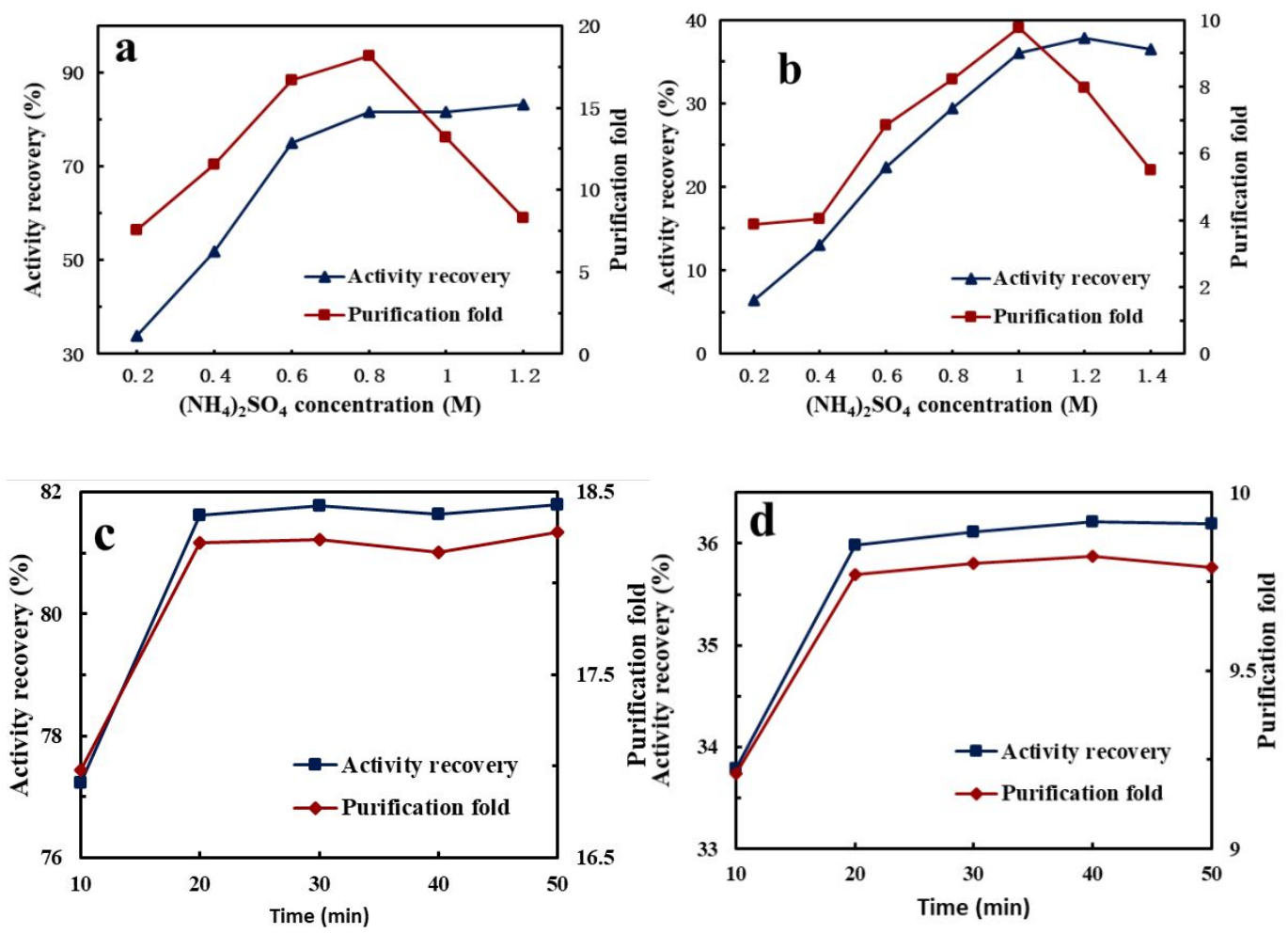

Figure S5. The effect of $\left(\mathrm{NH}_{4}\right)_{2} \mathrm{SO}_{4}$ concentration on the relative activity and purification fold of (a)

EGLEH and (b) CBHLEH; the effect of thermal precipitation time on relative activity and purification fold of (c) EGLEH and (d) CBHLEH. 

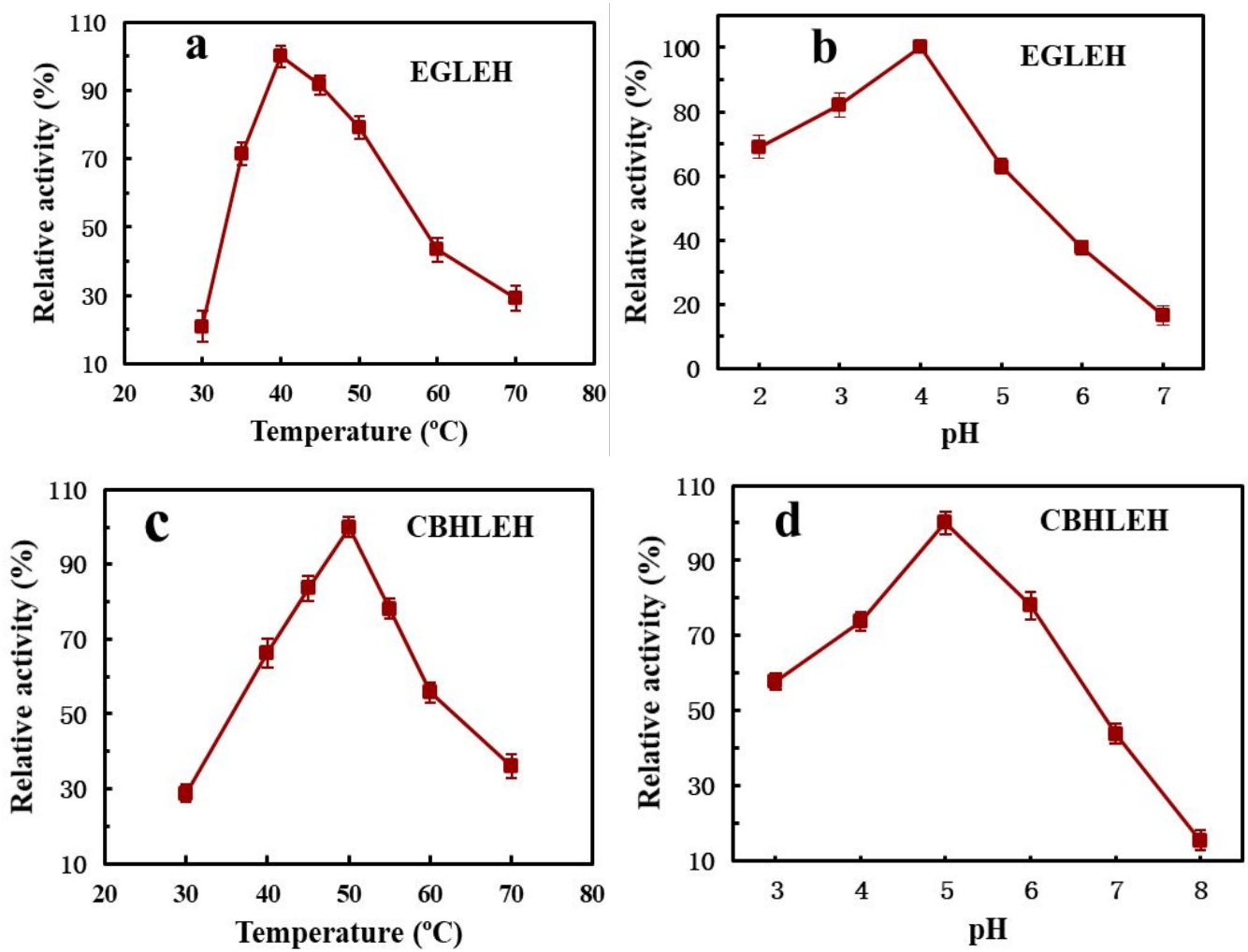

Figure S6. Effect of reaction temperature on the relative activity of (a) EGLEH and (c) CBHLEH; the effect of reaction $\mathrm{pH}$ on the relative activity of (b) EGLEH and (d) CBHLEH.
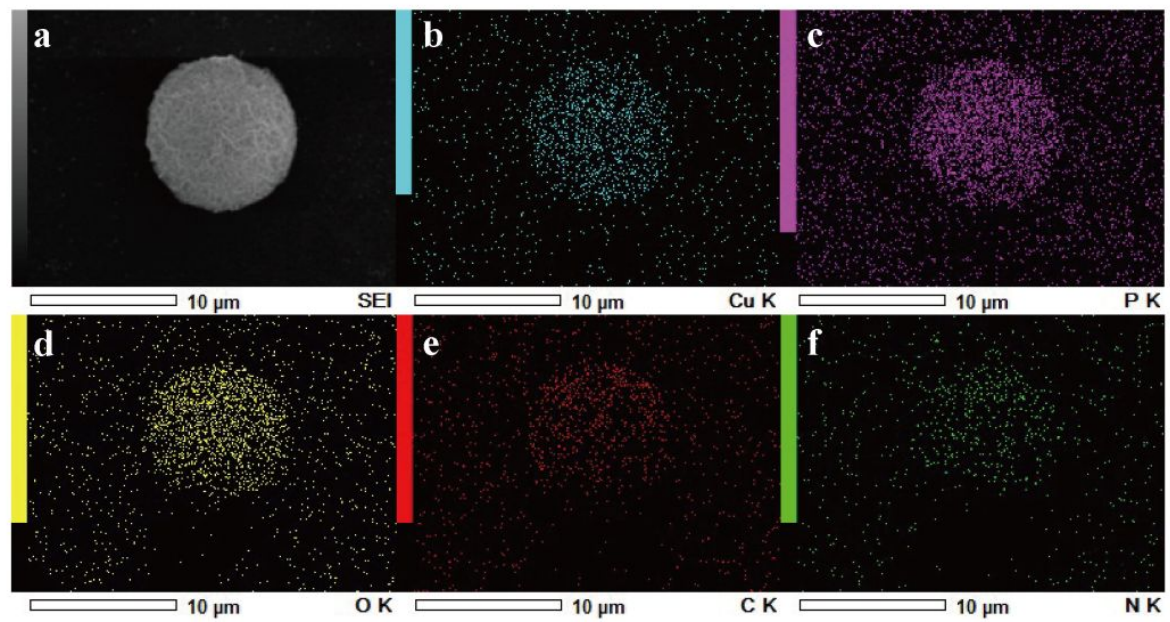

Figure S7. Scanning electron micrographs of ECG-NFs, and element mapping picture of (b) copper,

(b) phosphorous, (c) oxygen, (d) carbon, (e) nitrogen 

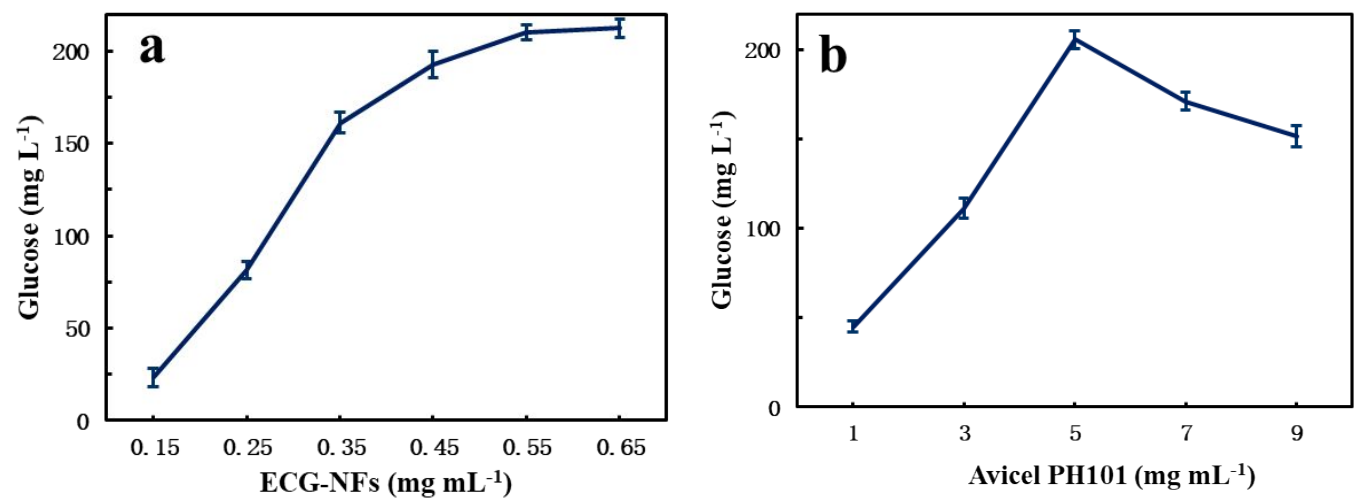

Figure S8. Effect of (a) concentration of ECG-NFs and (b) concentration of Avicel PH101 on the catalytic performance of ECG-NFs.

Table S1. The effect of IPTG $(\mathrm{mM})$ concentration on the specific enzyme activity of EGLEH and CBHLEH $\left(\mathrm{U} \mathrm{g}^{-1}\right)$.

\begin{tabular}{cccccc}
\hline & $0.15 \mathrm{mM}$ & $0.25 \mathrm{mM}$ & $0.35 \mathrm{mM}$ & $0.45 \mathrm{mM}$ & $0.55 \mathrm{mM}$ \\
\hline EGLEH $\left(\mathrm{U} \mathrm{g}^{-1}\right)$ & 7.57 & 8.42 & 7.68 & 7.84 & 8.27 \\
CBHLEH $\left(\mathrm{U} \mathrm{g}^{-1}\right)$ & 4.10 & 4.09 & 4.14 & 3.76 & 4.01 \\
\hline
\end{tabular}

Table S2. The effect of induce temperature and induce time on the specific enzyme activity of EGLEH and CBHLEH.

\begin{tabular}{ccccccc}
\hline & $15^{\circ} \mathrm{C}$ & $15^{\circ} \mathrm{C}$ & $25^{\circ} \mathrm{C}$ & $25^{\circ} \mathrm{C}$ & $37^{\circ} \mathrm{C}$ & $37^{\circ} \mathrm{C}$ \\
& $6 \mathrm{~h}$ & $12 \mathrm{~h}$ & $6 \mathrm{~h}$ & $12 \mathrm{~h}$ & $6 \mathrm{~h}$ & $12 \mathrm{~h}$ \\
\hline EGLEH $\left(\mathrm{U} \mathrm{g}^{-1}\right)$ & 4.88 & 8.21 & 4.19 & 5.11 & 4.08 & 3.7 \\
CBHLEH $\left(\mathrm{U} \mathrm{g}^{-1}\right)$ & 3.69 & 4.01 & 3.75 & 3.88 & 3.53 & 3.68 \\
\hline
\end{tabular}


Table S3. Purification results of EGLEH and CBHLEH by one cycle ITC and two cycle ITC.

\begin{tabular}{ccccc}
\hline recombinase & $\begin{array}{c}\text { Purification } \\
\text { methods }\end{array}$ & specific enzyme & enzyme activity & purification \\
& activity $\left(\mathrm{U} \mathrm{g}^{-1}\right)$ & recovery $(\%)$ & fold \\
\hline EGLEH crude enzyme & $/$ & 8.32 & 100 & 1 \\
EGLEH & $1 \times$ ITC & 151.09 & 81.56 & 18.16 \\
EGLEH & $2 \times$ ITC & 155.37 & 64.68 & 18.67 \\
\hline CBHLEH crude enzyme & $/$ & 4.08 & 100 & 1 \\
CBHLEH & $1 \times$ ITC & 39.86 & 35.98 & 9.77 \\
CBHLEH & $2 \times$ ITC & 40.62 & 27.92 & 9.96 \\
\hline
\end{tabular}




\section{Reference}

(1) Zhao, M.; Rong, J.; Han, J.; Zhou, Y.; Wang, Y. Novel synthesis strategy for biocatalyst: fast purification and immobilization of His-and ELP-tagged enzyme from fermentation broth. ACS Applied Materials \& Interfaces. 2019, 11, 31878-31888.

(2) Rong, J. H; Han, J.; Zhou, Y.; Wang, L.; Li, C. M.; Wang, Y. Process Integration of

Production, Purification, and Immobilization of $\beta$-Glucosidase by Constructing Glu-linkerELP-GB System. Ind. Eng. Chem. Res. 2018, 57, 15620-15631. 